\title{
Surface Anisotropy Orients Cell Divisions in Contact Guided Cells*
}

\author{
Gracjana KRZYSIEK-MĄCZKA and Włodzimierz KOROHODA
}

Accepted October 10, 2007

\begin{abstract}
Gracjana KrZYSIEK-MĄCZKA G., KorohodA W. 2008. Surface anisotropy orients cell divisions in contact guided cells. Folia biol. (Kraków) 56: 13-19.

The orientation of cell elongation and the plane of cell division were determined in cells growing under isotropic conditions on a plain glass surface or under anisotropic conditions on a scratched glass surface. Four cell lines were analysed, each showing various degrees of contact guidance. Human skin fibroblasts and the skin keratinocyte cell line $\mathrm{HaCaT}$ oriented randomly on the smooth isotropic surface of glass, grew and divided randomly. By contrast, on an anisotropic scratched surface these cells showed contact guidance, elongated along scratches, and their planes of division were perpendicular to the long axis of the cell. In these two cell types there was a high degree of correlation between the cell alignment and the plane of cell division, which shows that extracellular factors can influence or even determine the latter. In cell lines in which contact guidance under anisotropic conditions was less evident, viz. the lung endothelial cell line HLMEC and the skin endothelial cell line HSkMEC, the alignment of cell division planes was less ordered. This report concentrates on quantitative phenomenological descriptions of the orientation of cell division as determined by contact guidance.
\end{abstract}

Key words: Contact guidance, cell polarization, cell division, cytokinesis.

Gracjana KRZYSIEK-MACZKA, Wlodzimierz KOROHODA, Department of Cell Biology, Faculty of Biochemistry, Biophysics, and Biotechnology, Jagiellonian University, Gronostajowa 7, 30-387 Kraków, Poland.

E-mail:Korohoda@mol.uj.edu.pl

Active cell movement and often concomitantly occurring cell divisions are considered to have a major influence upon developmental processes in multicellular organisms (CASTOR 1968; KOROHODA 1972; ZHAO et al. 1999; LECHLER \& FUCHS 2005; CIRUNA et al. 2006). These two cell activities play a pivotal role in the positioning of cells in tissues and in organogenesis. Asymmetric cell divisions are involved in the stratification and differentiation of mammalian skin (LECHLER \& FUCHS 2005).

In skin, the orientation of the cleavage plane determines whether the daughter cells remain within the original cell layer attached to the basement membrane, or shift perpendicularly to commence differentiation followed by apoptosis and finally cornification and death (SMACK et al. 1994). Factors which determine the cleavage planes in asymmetrically dividing stem cells might therefore be expected to influence the fate of daughter cells, deciding which maintains features of the stem cell and which will differentiate.

The plane of cell division depends upon both intrinsic and extrinsic (extracellular) factors
(KOROHO- DA \& RZEHAK 1972; ZHAO et al. 1999; LEHLER \& FUCHS 2005). Genetic aberrations have been shown to cause neurulation defects in vertebrate cells which affect the formation and orientation of both mitotic spindles and cleavage furrows of dividing cells (CIRUNA et al. 2006). Here we report on in vitro studies of four cell types under isotropic and anisotropic culture conditions in order to determine the relationship of cell movement and orientation of their planes of cell division. The experiments were conducted under conditions in which single cells contacted single scratches in glass, but without physical association with other cells or scratches.

\section{Material and Methods}

\section{Chemicals and reagents}

C e $11 \mathrm{~s}$ : Normal human skin fibroblasts were grown in DMEM (Sigma Chemical Co.) supplemented with $10 \%$ foetal calf serum (Gibco BRL), 
the antibiotics penicillin, streptomycin, neomycin (Polfa Tarchomin S.A. Poland), in humidified 5\% $\mathrm{CO}_{2}, 95 \%$ air at $37^{\circ} \mathrm{C}$. Cells were grown in $25 \mathrm{~cm}^{2}$ flasks (Sarsteadt) and passaged once a week.

The Human Keratinocyte Cell Line (HaCaT) was a kind gift from Prof. A. KLEIN, Kraków. Cells were grown in DMEM-g medium supplemented with $1000 \mathrm{mg} / \mathrm{ml}$ glucose, Gluta MAX-I and pyruvate (Gibco BRL, Invitrogen), with the addition of $10 \%$ foetal calf serum, penicillin, streptomycin and neomycin under conditions described above. Cells were grown in $25 \mathrm{~cm}^{2}$ flasks (Sarsteadt) and passaged once a week.

Human Lung Microvascular Endothelial Cells (HLMEC) and Human Skin Microvascular Endothelial Cells (HSkMEC) were a kind gift from Prof. J. Pryjma, Kraków. Cells were grown in OptiMEM (Gibco BRL, Invitrogen), supplemented with $3 \%$ foetal calf serum (Gibco BRL), penicillin, streptomycin and neomycin (Polfa Tarchomin S.A.) under conditions described above. Cells were grown in $7 \mathrm{~cm}^{2}$ glass dishes (Simax Czech Republic) and passaged biweekly.

HLMEC, HSkMEC and HaCaT cells were plated at a density of $3 \times 10^{4}$ cells per $7 \mathrm{~cm}^{2}$ and fibroblasts were plated at a density of $1.5 \times 10^{4}$ cells per $7 \mathrm{~cm}^{2}$ onto plain and grooved glass coverslips, placed in Petri glass dishes (Simax Czech Republic) under conditions described above. After 24 hours, the cultures consisted of mostly single cells which were fixed and photographed.

\section{Substratum patterning}

The anisotropic surface was made with corund powder on glass coverslips (Szklarskie Zakłady Przetwórcze "Przełom", Poland). The scratches were 0.1-2.0 $\mu \mathrm{m}$ wide and 0.1-1 $\mu \mathrm{m}$ deep (STĘPIEŃ et al. 1999).

\section{Microphotography}

Cells were fixed with $3.7 \%$ formaldehyde and stained with trypan blue (Chemapol, Praha, Czechoslovakia) in order to distinguish dividing cells for image analysis. Orientation was then calculated with the use of the image analysis program Migra written by dr R. TOKARSKI (The Institute of Nuclear Physics, Polish Academy of Sciences, Kraków).

\section{Image analysis}

Cell images, observed with a 10x objective of Hund Wilovert S AFL inverted phase contrast microscope, were recorded with a Hitachi CCD camera (MADEJA \& KOROHODA 1996).
The digitised pictures were analysed with the computer program Migra which calculated parameters relative to cell orientation (DUNN \& BROWN 1986).

\section{Cell orientation}

Cell orientation is expressed in degrees, where $90^{\circ}$ corresponds to the orientation of the long axis parallel to scratches, whereas $0^{\circ}$ and $180^{\circ}$ corresponds to orientation perpendicular to scratches. In the case of dividing cells, $90^{\circ}$ corresponds to the cleavage plane orientation perpendicular to scratches, whereas $0^{\circ}$ and $180^{\circ}$ to orientation parallel to scratches (ZHAO et al. 1999).

\section{Quantification of long axis orientation}

Long axis orientation was defined as the function of the average directional cosine $\sum_{\mathrm{n}} \cos 2 \theta / \mathrm{n}$ (ERICKSON \& NUCCITELLI 1984; GRULER \& NUCCITELLI 1991). $\Theta$ is defined as the directional angle between the long axis of the cell and an arbitrary $0 \mathrm{Y}$ axis perpendicular to the horizontal axis of the field of view in isotropic conditions on smooth glass coverslips and between the long axis of the cell and the axis perpendicular to scratches. The parameter would equal -1 for long axis orientation parallel to scratches, 1 for a perpendicular orientation and 0 for random orientation.

\section{Quantification of cleavage orientation}

Results were calculated from polar diagrams of cell division orientation introduced by ZHAO (ZHAO et al. 1999). The cleavage plane orientation was defined as the function of average directional cosine $\sum_{\mathrm{n}} \cos 2 \theta / \mathrm{n}$ (ERICKSON \& NUCCITELLI 1984; GRULER \& NUCCITELLI 1991). Ois defined as the directional angle between the cleavage plane and an arbitrary $0 \mathrm{X}$ axis parallel to the horizontal axis of the field of view in isotropic conditions on smooth glass coverslips, and between the cleavage plane and the axis parallel to scratches. The parameter would equal -1 for the cleavage plane orientation perpendicular to scratches, 1 if parallel and 0 for random orientation.

\section{Statistical analysis}

For each value measured, 50 cells were analysed. Mean and standard errors (SEM) for each parameter were calculated. The polarisation of cell orientation was evaluated by determining the directional cosines. The probability that the orientation is random is given by

$$
\mathrm{P}=\mathrm{e}^{-\left(\mathrm{L}^{2} \mathrm{n}\right)\left(10^{-4}\right)}
$$

where $\mathrm{L}=\left(\left(\sum_{\mathrm{n}} \sin 2 \theta\right)^{2}+\left(\sum_{\mathrm{n}} \cos 2 \theta\right)^{2}\right)^{1 / 2} / \mathrm{n}(0.01)$ and $n$ is the total number of cells. A probability 
level of 0.01 was used as the limit for significant directional orientation (ERICKSON \& NUCCITELLI 1984).

\section{Results and Discussion}

In the first experiments cell shape polarization was compared under conditions in which cells grew on isotropic surfaces, and under anisotropic conditions in which cells were in contact with single scratches in four cell lines. The polarization of cell shape is considered a measure of cell contact guidance (CLARK et al. 1990; DALBY et al. 2004; JOHNSON et al. 2006). The results are shown in Figure 1a-f and Table 1.

On isotropic, smooth glass surfaces, all four cell lines tested showed random orientation of their
A

$f(x)$

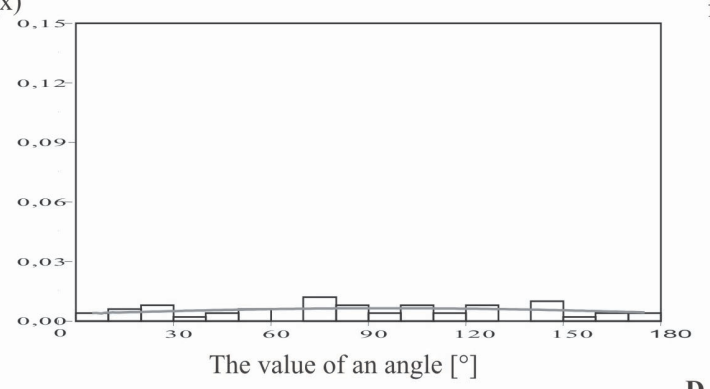

C

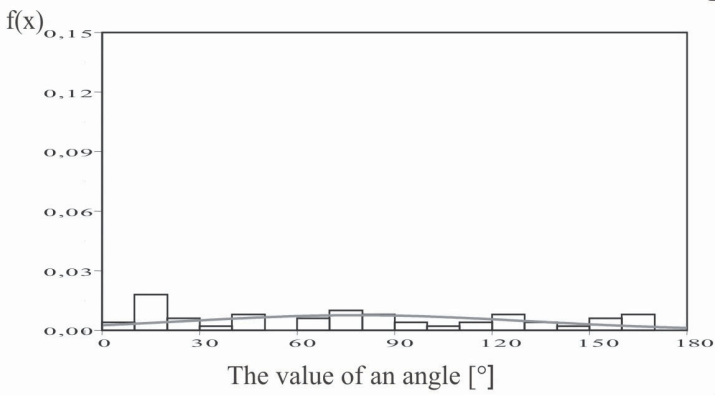

$\mathbf{E}$ $f(x)$

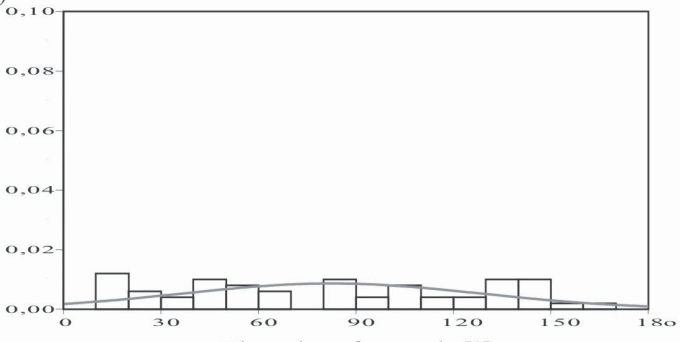

G

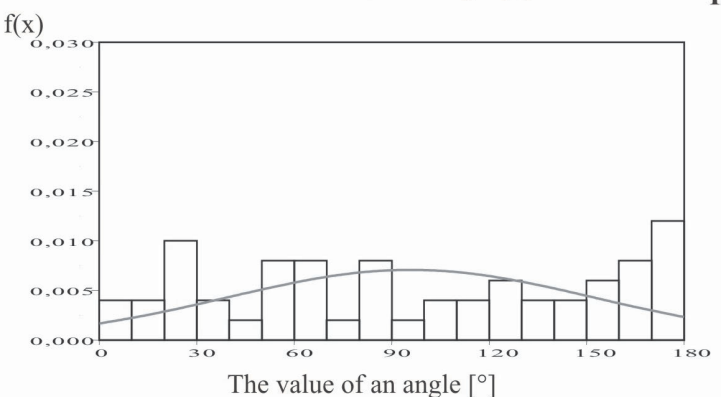

B

$f(x)$

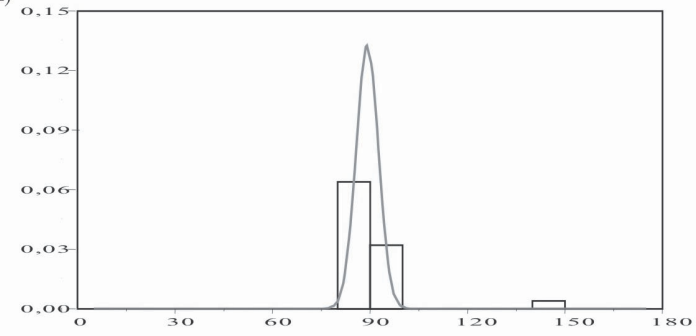

The value of an angle $\left[{ }^{\circ}\right]$

$f(x)$

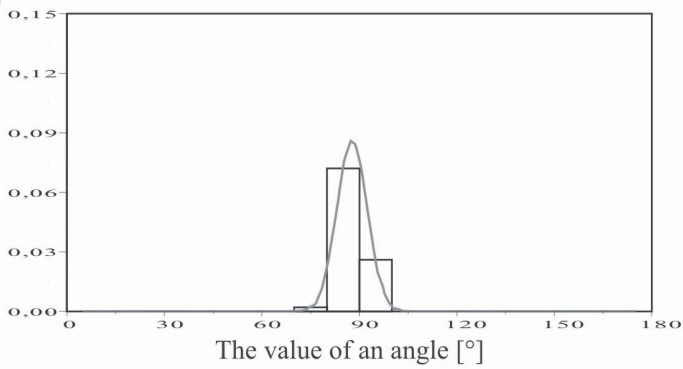

F(x)

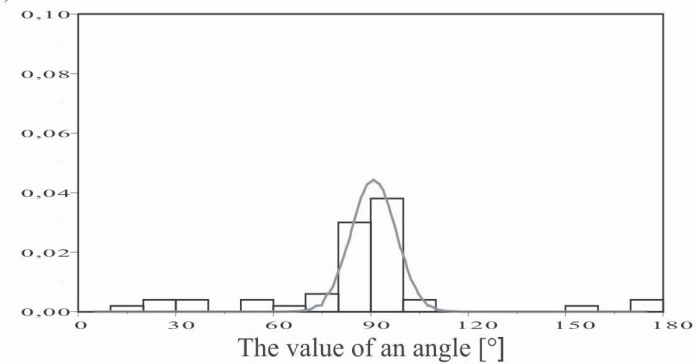

f(x)

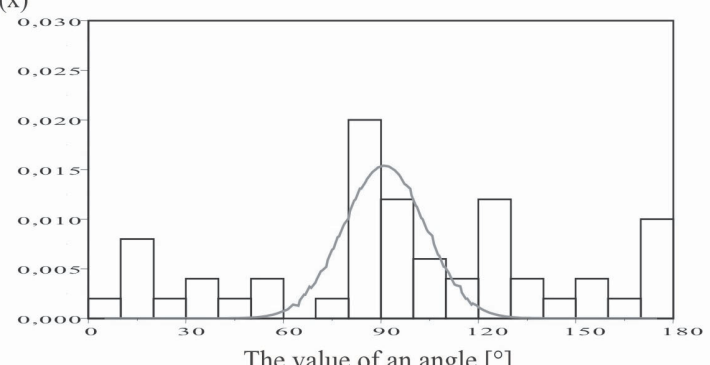

Fig. 1. Histograms showing the values of the angles between the long axis of the cell and the arbitrary OY axis under isotropic conditions on smooth glass coverslips (A-fibroblasts, C-HaCaT, E-HSkMEC, G-HLMEC) and between the long axis of the cell and the axis perpendicular to single scratches on the glass (B-fibroblasts, D-HaCaT, F-HSkMEC, H-HLMEC). 90 corresponds to parallel orientation of the cell. The alignment and the shape of the cell were assesed $24 \mathrm{~h}$ after seeding. A Gaussian distribution was fitted to each histogram.

*f(x)-probability density function

*Cell orientation is expressed in degrees. 
Table 1

Parameters characterizing the orientation of the long axis of a cell under isotropic conditions (smooth glass coverslips) and under anisotropic conditions on single scratches in glass 24 hours after seeding

\begin{tabular}{|l|c|c|c|c||}
\hline \multirow{2}{*}{ Cells } & \multicolumn{2}{|c|}{ Average directional cosine $\left(\sum_{\mathrm{n}} \cos 2 \theta / \mathrm{n}\right)$} & \multicolumn{2}{c|}{ Probability of random orientation $(\mathrm{P})}$. \\
\cline { 2 - 5 } & Isotropic surface & Anisotropic surface & Isotropic surface & Anisotropic surface \\
\hline \hline Fibroblasts & $-0.106+/-0.100$ & $-0.943+/-0.038$ & 0.47 & $4.91 \times 10^{-19^{* *}}$ \\
\hline HaCaT & $0.052+/-0.105$ & $-0.988+/-0.003$ & 0.65 & $3.13 \times 10^{-21^{* *}}$ \\
\hline HSkMEC & $-0.103+/-0.089$ & $-0.674+/-0.088$ & 0.56 & $7.43 \times 10^{-10^{* *}}$ \\
\hline HLMEC & $-0.123+/-0.102$ & $0.210+/-0.109$ & 0.45 & 0.07 \\
\hline
\end{tabular}

$* \Theta$ is defined as the directional angle between the long axis of the cell and an arbitrary $0 \mathrm{Y}$ axis under isotropic conditions on smooth glass coverslips and between the long axis of the cell and the axis perpendicular to a single scratch in the glass. The average directional cosine represents the degree of polarization of the orientation of the long axis of the cell. This parameter would equal -1 if the the long axis oriented parallel to scratches, 1 if it was perpendicular, while for random orientation the value would be 0 .

$\uparrow \mathrm{P}$-probability that the orientation is random is given by

$\mathrm{P}=\mathrm{e}^{-\left(\mathrm{L}^{2} \mathrm{n}\right)\left(10^{-4}\right)}$

where $\mathrm{L}=\left(\left(\sum_{\mathrm{n}} \sin 2 \theta\right)^{2}+\left(\sum_{\mathrm{n}} \cos 2 \theta\right)^{2}\right)^{1 / 2} / \mathrm{n}(0.01)$ and $\mathrm{n}$ is the total number of cells $(\mathrm{n}=50$ for each cell type $)$. A probability level of 0.01 was used as the limit for significant directional orientation (ERICKSON \& NUCCITELLI 1984).

** - highly significant

long cell axes (Fig. 1 a,c,e,g). Upon contact with anisotropic glass with scratches, the human skin fibroblasts and $\mathrm{HaCaT}$ skin keratinocytes oriented with their long axes aligned along the scratches (Fig. 1 b,d and Table 1) showing typical behavior of contact guided cells (KOROHODA \& MADEJA 1997). The single HSkMEC cells showed some orientation on scratches but much less than fibroblasts or $\mathrm{HaCaT}$ cells, whereas lung endothelial HLMEC oriented randomly and did not show contact guidance of cell shape (Fig. 1 f,h and Table 1).

Figure 2 illustrates to what extent contact of $\mathrm{Ha}-$ CaT cells with single scratches in the glass surface influences elongation of cell shape. Similar observations were found for fibroblasts. Such cells divided with the long axes of their mitotic spindles aligned along scratches. The plane of division was exactly perpendicular (Fig. 2).

Since the estimation of the parameter of the plane of cell division and axis of mitotic spindles was straightforward under these experimental conditions, we applied a statistical analysis of the behaviour of cells on smooth glass surfaces and those elongated along the glass scratches, similar to ZHAO (ZHAO et al. 1999) who found that an electric field can orient cell divisions. As shown in Figures 3 and 4, the orientation of planes of cell division in all four tested cell lines on an isotropic smooth glass surface is random. However, fibro-

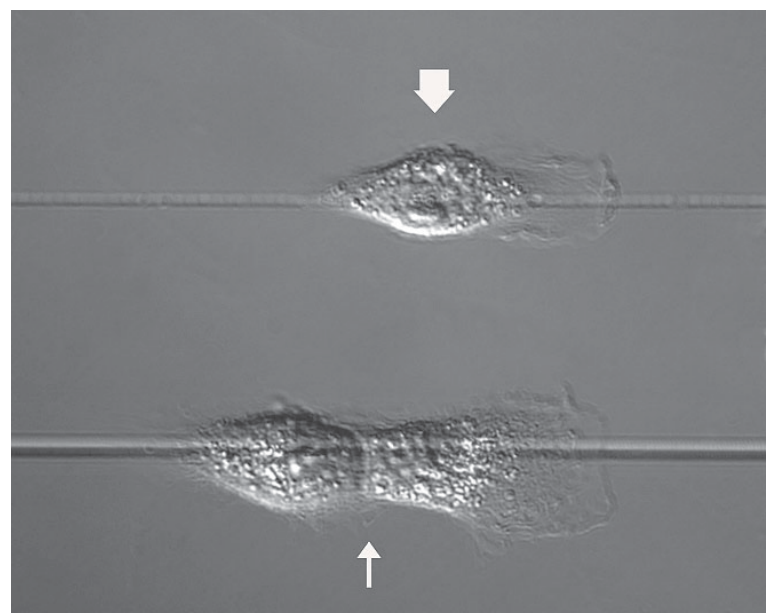

Fig. 2. The influence of single scratches in glass surface on the orientation and shape of a single $\mathrm{HaCaT}$ cell and on $\mathrm{HaCaT}$ cell division plane orientation. The single cell alignes along the scratch, showing typical contact guidance phenomena (thick arrow). In a mitotic cell the division plane orients exactly perpendicular to the scratch (thin arrow).

blasts and HaCaT cells which revealed contact guidance on anisotropic glass scratches, showed cleavage planes almost perpendicular to the axis of scratches. In particular, in the case of skin fibroblasts 48 out of 50 randomly analysed cells had divided with the cleavage planes $\pm 10^{\circ}$ from $90^{\circ}$, i.e. 
A $_{\mathrm{f}(\mathrm{x})}$

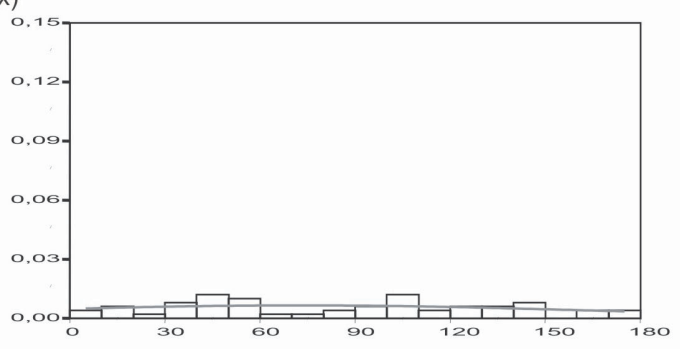

$\mathrm{C}_{\mathrm{f}(\mathrm{x})}$

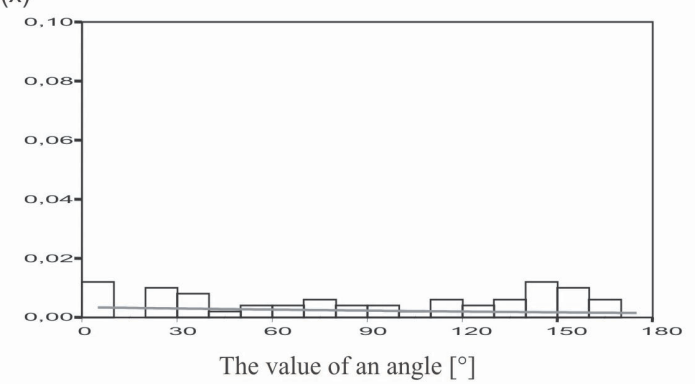

E

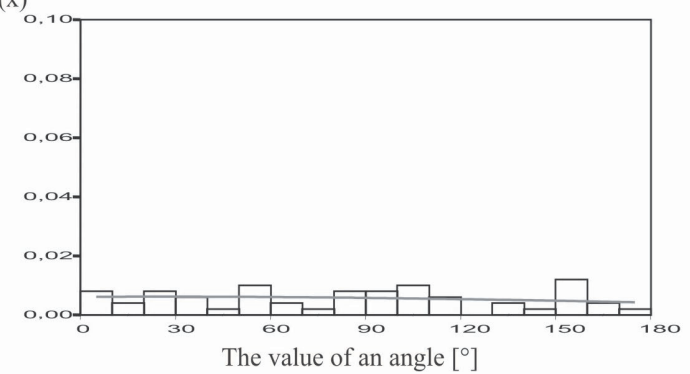

G $f(x)$

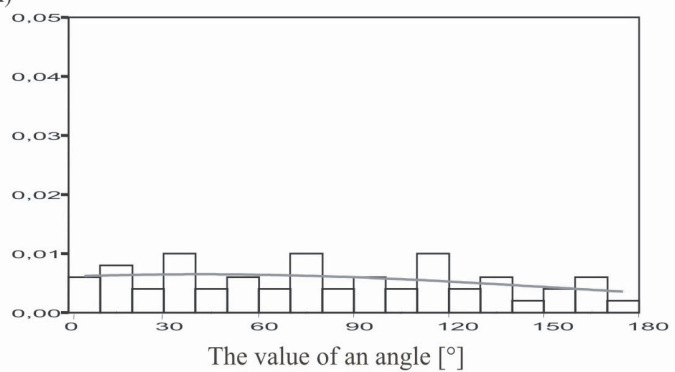

B $f(x)$

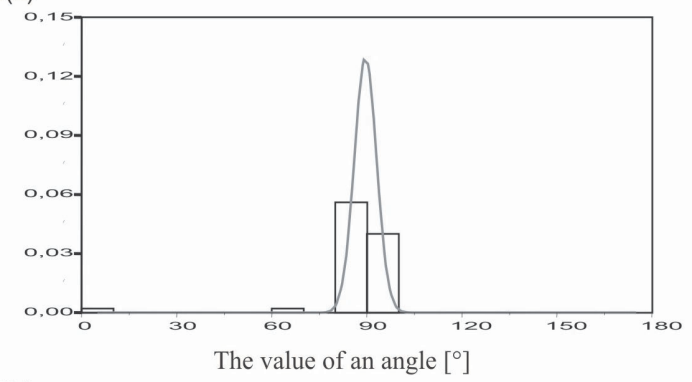

D $\mathrm{f}(\mathrm{x})$

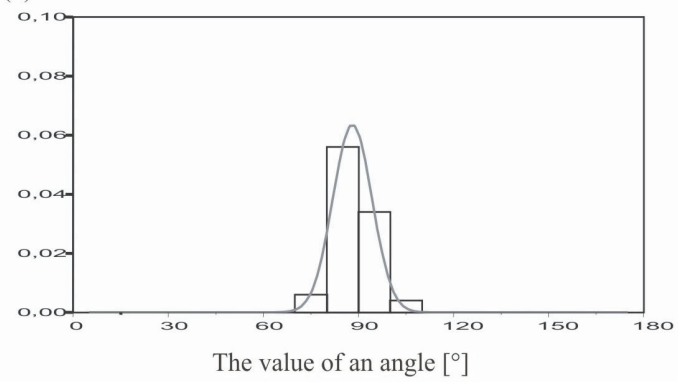

F

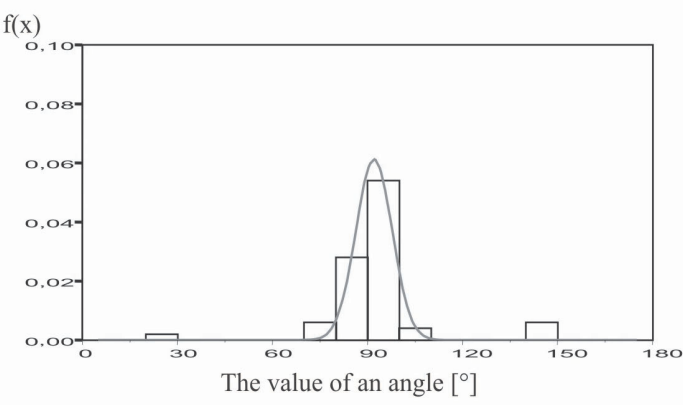

H

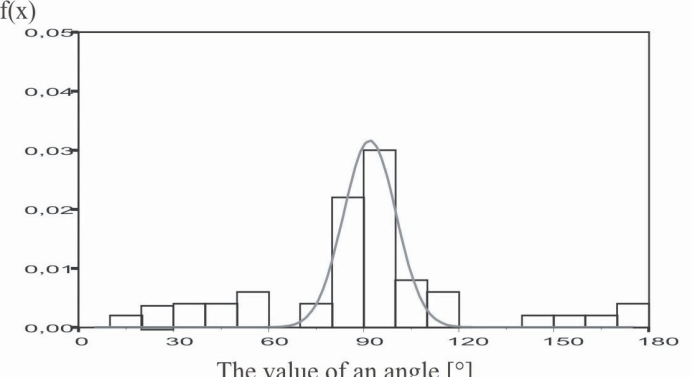

Fig. 3. Histograms showing the values of the angles between the division plane of the cell and the arbitrary OX axis under isotropic conditions on smooth glass coverslips (A-fibroblasts, C-HaCaT, E-HSkMEC, G-HLMEC) and between the division plane of the cell and the axis parallel to single scratches on the glass (B-fibroblasts, D-HaCaT, F-HSkMEC, H-HLMEC). $90^{\circ}$ corresponds to perpendicular orientation of the division plane of the cell. The alignment and the shape of the cell were assesed $24 \mathrm{~h}$ after seeding. A Gaussian distribution was fitted to each histogram.

* $\mathrm{f}(\mathrm{x})$-probability density function

*Cell orientation is expressed in degrees.

a position perpendicular to scratches and with their mitotic spindles almost parallel to the scratches. However, in endothelial cells, which showed less obvious contact guidance, the orientation of cell divisions was much less ordered than in the fibroblasts or $\mathrm{HaCaT}$ cells.

The results presented show that the planes of cell division can be experimentally oriented in those cells which show contact guidance elongating along anisotropic surfaces. Such observations suggest a simplification of experimental research to determine how the plane of cell divisions in tissues of multicellular animals relates to the anisotropy in local cell environment, contributed by extracellular matrix macromolecules, sculpture of substratum, and the surfaces of adjacent cells, in addition to genetic determinants and diffusible molecules. 
Isotropic surface

A

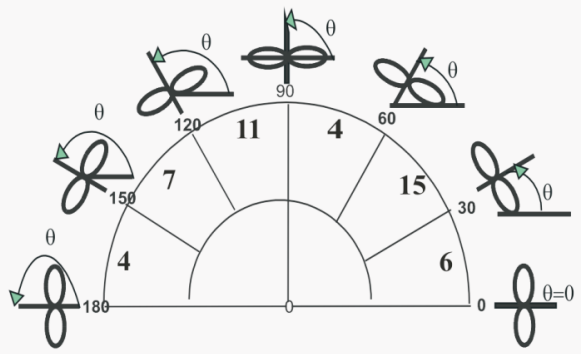

C

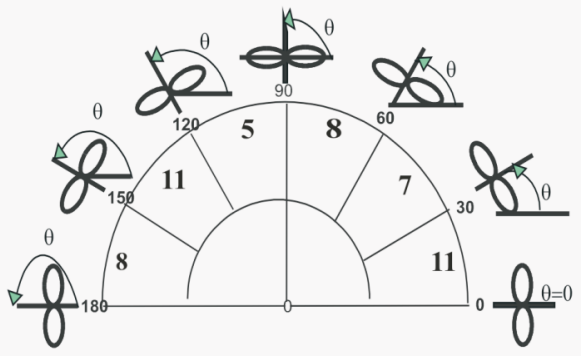

E

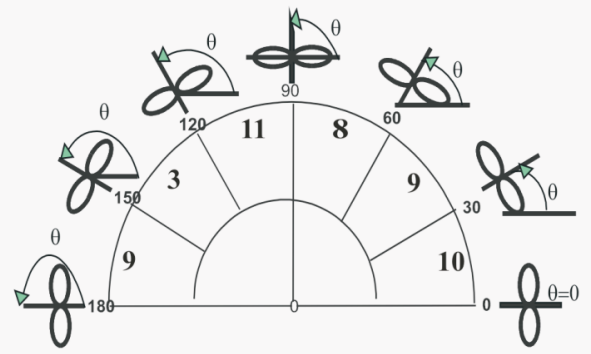

G

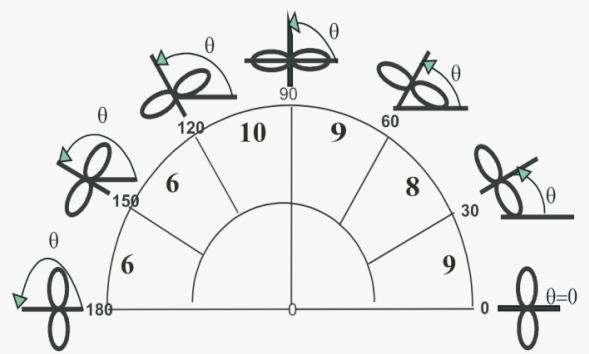

Anisotropic surface

Scratches position

B in relation to

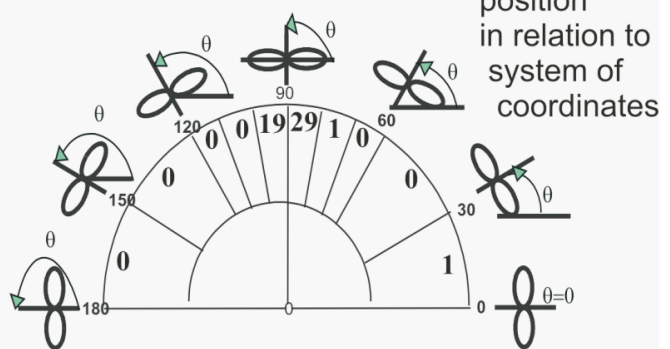

D

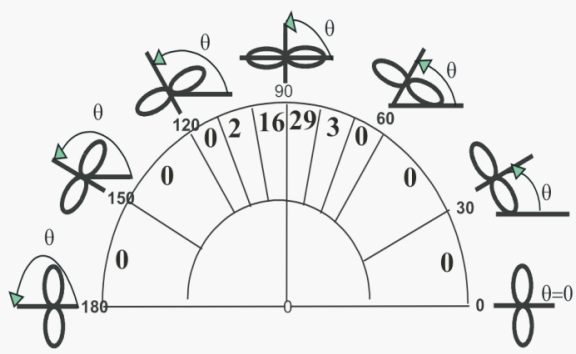

F

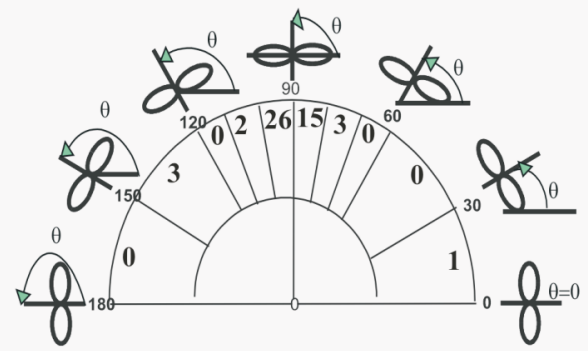

$\mathrm{H}$

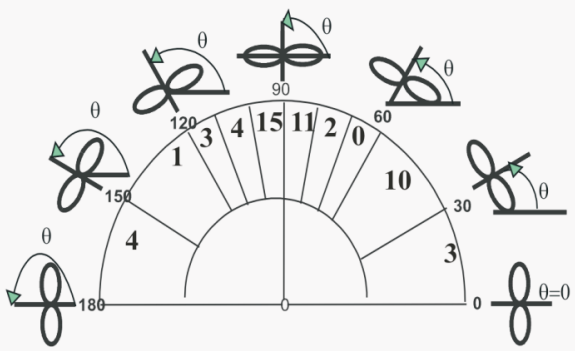

Fig. 4. Polar diagrams showing the orientation of division planes of the cells under isotropic conditions on smooth glass coverslips (A-fibroblasts, C-HaCaT, E-HSkMEC, G-HLMEC) and on single scratches on glass-anisotropic conditions (B-fibroblasts, D-HaCaT, F-HSkMEC, H-HLMEC) 24h after seeding. The total number of cells in each range of angles is indicated numerically. In the case of cells under anisotropic conditions between 60 and 120 degrees, the range was applied every 10 degrees.

The presentation of behaviour or morphology of a few selected cells as results of experiments without statistical analysis of larger cell numbers can be treated as an illustration but not documentation of observations (WALIGÓRSKA et al. 2007). In this report we concentrated, therefore, on quantitative phenomenological description of the dependence of cell division orientation upon cell shape influenced by contact guidance. The questions of why and how cell shape influences the plane of cell division shall be considered in a separate paper.

\section{Acknowledgements}

The authors cordially thank Prof. D. WOOLLEY, University of Manchester, UK for valuable discussions and language corrections. 
Table 2

Parameters characterizing the orientation of the cell division plane under isotropic conditions (smooth glass coverslips) and under anisotropic conditions on single scratches in glass 24 hours after seeding

\begin{tabular}{|c|c|c|c|c|}
\hline \multirow{2}{*}{ Cells } & \multicolumn{2}{|c|}{$\begin{array}{c}\text { Average directional cosine } \\
\left(\sum_{\mathrm{n}} \cos 2 \theta / \mathrm{n}\right)\end{array}$} & \multicolumn{2}{c|}{} \\
\cline { 2 - 5 } & Isotropic surface & Anisotropic surface & Isotropic surface & Anisotropic surface \\
\hline \hline Fibroblasts & $-0.086+/-0.093$ & $-0.945+/-0.040$ & 0.54 & $3.78 \times 10^{-19^{* *}}$ \\
\hline HaCaT & $0.140+/-0.095$ & $-0.976+/-0.006$ & 0.28 & $1.9 \times 10^{-211^{* *}}$ \\
\hline HSkMEC & $-0.032+/-0.107$ & $-0.864+/-0.055$ & 0.86 & $5.72 \times 10^{-16^{* *}}$ \\
\hline HLMEC & $-0.049+/-0.101$ & $-0.541+/-0.094$ & 0.38 & $4.28 \times 10^{-6}$ \\
\hline
\end{tabular}

$* \Theta$ is defined as the directional angle between the cell division plane and an arbitrary $0 \mathrm{X}$ axis under isotropic conditions on smooth glass coverslips and between the cell division plane and the axis parallel to a single scratch in the glass. The average directional cosine represents the degree of polarization of the orientation of the axis of cell division. This parameter would equal -1 if the cell division plane was perpendicular to scratches, 1 if it was parallel, while for random orientation the value would be 0 . $\dagger \mathrm{P}$-probability that the orientation is random is given by

$\mathrm{P}=\mathrm{e}^{-\left(\mathrm{L}^{2} \mathrm{n}\right)\left(10^{-4}\right)}$

Where $\mathrm{L}=\left(\left(\sum_{\mathrm{n}} \sin 2 \theta\right)^{2}+\left(\sum_{\mathrm{n}} \cos 2 \theta\right)^{2}\right)^{1 / 2} / \mathrm{n}(0.01)$ and $\mathrm{n}$ is the total number of cells $(\mathrm{n}=50$ for each cell type). A probability level of 0.01 was used as the limit for significant directional orientation (ERICKSON \& NUCCITELLI 1984).

** - highly significant

\section{References}

CASTOR L. N. 1968. Flattening movement and control of division of epithelial-like cells. J. Cell Physiol. 75: 57-64.

Ciruna B., Jenny A., LeE D., MLODZIK M., SChier A. F. 2006. Planar cell polarity signaling couples cell division and morphogenesis during neurulation. Nature 439: 220-224.

Clark P., Connolly P., Curtis A. S. G., Dow J. A. T., WILKINSON C. D. W. 1990. Topographical control of cell behaviour II. Multiple grooved substrata. Development 108: 635-644.

Dalby M. J., GAdEGAARD N., Riehle M. O., Wilkinson C. D. W., CURTIS A. S. G. 2004. Investigating filopodia sensing using arrays of defined nano-pits down to $35 \mathrm{~nm}$ diameter in size. Int. J. Biochem. Cell Biol. 36: 2005-15.

DUNN G. A., BROWN A. F. 1986. Alignment of fibroblasts on grooved surfaces described by a simple geometric transformation. J. Cell Sci. 83: 313-340.

ERICKSON C. A., NUCCITELLI R. 1984. Embryonic fibroblast motility and orientation can be induced by physiological electric fields. J. Cell Biol. 98: 296-307.

GRULER H., NUCCITELLI R. 1991. Neural crest cell galvanotaxis: new data and a novel approach to the analysis of both galvanotaxis and chemotaxis. Cell Motil. Cytoskeleton 19: 121-133.

JOHNSON W. E., WoOtTON A., El Haj A., EisEnStein S. M., CURTIS A. S., ROBERTS S. 2006. Topographical guidance of intervertebral disc cell growth in vitro: towards the development of tissue repair strategies for the anulus fibrosus. Eur. Spine J. 15: S389-S396.
KOROHODA W. 1972. Some aspects of the interrelation among cell locomotion, contact phenomena, and cellular multiplication. Acta protozool. 11: 161-172.

KOROHODA W., RZEHAK K. 1972. Local contractionrelaxation processes in Amphibian eggs induced by ACelectric fields. Acta protozool. 11: 355-360.

KorohodA W., MADEJA Z. 1997. Contact of sarcoma cells with aligned fibroblasts accelerates their displacement: computer-assisted analysis of tumour cell locomotion in coculture. Biochem. Cell Biol. 75: 263-76.

LECHLER T., FUCHS E. 2005. Asymetric cell divisions promote stratification and differentiation in mammalian skin. Nature 437: 275-280.

MAdEJA Z., KOROHODA W. 1996. Applications of computer - assisted image analysis to cell biology. Postępy Biologii Komórki 23: 457-476. (In Polish).

SMACK D. P., Korge B. P., BethesdA J. W. D. 1994. Keratin and keratinization. J. Am. Acad. Dermatol. 30: 85-102.

STĘIEŃ E., STANISZ J., KOROHODA W. 1999. Contact guidance of chick embryo neurons on single scratches in glass and on underlying aligned human skin fibroblasts. Cell Biol. Intern. 23: 105-116.

ZhaO M., ForRester J. V., MCCAiG C. D. 1999. A small, physiological electric field orients cell division. Proc. Natl. Acad. Sci. USA 96: 4942-4946.

WALigórska A., WiANECKA-SKOCZEŃ M., NowAK P., KOROHODA W. 2007. Some difficulties in research into cell motile activity under isotropic conditions. Folia biol. (Kraków) 55: 9-16. 